\title{
Influence of the Harvesting and Ensilage Technology on the Quality of Maize Straw Silage
}

\author{
Jacek Przybył ${ }^{1, *}$, Dawid Wojcieszak ${ }^{1}$, Ireneusz Kowalik ${ }^{1}$, Jacek $_{\text {Dach }}{ }^{1}$ \\ ${ }^{1}$ Poznan University of Life Sciences, Institute of Biosystems Engineering, WojskaPolskiego 50, 60-625 Poznan, Poland
}

\begin{abstract}
The aim of the study was to assess how the harvesting and ensilage technology influenced the quality of maize straw silages. The research findings showed that it was best to make maize straw silage in a flexible silo, whereas it was least favourable to make it in a film-covered field prism. The choice of the adequate ensilage method results in a high quality silage even if there is high content of dry matter in maize straw.
\end{abstract}

\section{Introduction}

At present whole maize plants are the most common substrate for biogas production in Central Europe [1]. However, the use of full-value agricultural products for energy purposes increases their prices and reduces the profitabilityof biogas production [2]. Therefore, it is necessary to develop alternative energy substrates, including agricultural waste and by-products [3]. Maize straw is a by-product available in large amounts, which has not been fully used so far. The production of maize grains leaves crop residue, such as stalks, leaves, cob cores and cob-covering leaves. The crop residue makes $47-50 \%$ of the dry weight yield of whole maize plants [4]. There is $0.15 \mathrm{~kg}$ of cob cores, $0.22 \mathrm{~kg}$ of leaves, 0.14 $\mathrm{kg}$ of cob-covering leaves and $0.5 \mathrm{~kg}$ of stalks per one kilogram of the dry weight of maize grains [4].

In 2015 maize grain production in Poland amounted to 3.16 million tonnes [5]. Our estimates show that the annual maize straw production in Poland may amount to as much as 4 million tonnes. There is high potential of maize straw as a substrate for biogas production in Poland [6-8]. In Poland maize is harvested for grain in late autumn (October-November), when the air temperature drops and the humidity rises. Under these conditions the moisture of maize grains usually ranges from $30 \%$ to $35 \%$. The moisture of maize residue ranges from $47 \%$ to $66 \%$ [9]. It is impossible to dry maize straw in the field. Ensilage is the only reasonable solution in the storage of maize straw.

The aim of the study was to assess how the harvesting and ensilage technology influenced the quality of maize straw silages.

\section{Material and methods}

The maize straw ensilage experiment was conducted during production at the Stary Gołębin farm, which belongs to the Top Farms Wielkopolska company. It was abivariate experiment. The first-order factor was thetype of container where maize straw was ensilaged, i.e.

- aheap,

- a flexible silo,

- $\quad$ film-wrapped cylindrical bales.

The second-order factor was the maize straw ensilage method, i.e.

- natural ensilage (CCSN),

- ensilage aided with lactic acid bacterial strains (Pediococcusacidilactici 33-11 NCIMB 30085, $P$. acidilactici 33-06 NCIMB 30086, Lactobacillus plantarum LSI NCIMB 30083, L. plantarum L- 256 NCIMB 30084, Enterococcus faecium M74 NCIMB11181)(CCS1),

- $\quad$ ensilage aided with an organic preparation (sodium benzoate, propionic acid and sodium propionate) (CCS2).

Silages were made from the straw left after the maize cultivar PR39A79 (Pioneer company, FAO 300) had been harvested for grain. The dry matter content in the crop residue was $68 \%$ and the organic dry matter content was $87.11 \%$.

The yield of maize dry matter consisted of cobs $(59 \%)$, stalks (19\%), leaves (14\%) andhusks $(8 \%)$.

Maize straw was harvested with a New Holland 644 variable chamber baler and a Pöttinger Jumbo 7200 Powermatic loader wagon.

\section{1 Laboratory analyses of silages}

Maize straw samples weighing about $2 \mathrm{~kg}$ were collected from a flexible silo, prism and film-wrapped cylindrical bales in order to conduct physical and chemical analyses. The analyses of raw silage samples were conducted in the laboratory of the Department of Animal Nutrition and Feed Management, Poznan University of Life Sciences, Poland. The laboratory analyses of the samples included:

- the analysis of dry matter content, 
- the analysis of the content of volatile fatty acids,

- $\mathrm{pH}$ measurement.

The dry matter content was determined by means of the drying and weighing method, according to the Polish Standard PN-ISO 6496:2002. Liquid chromatography was applied to measure the content of volatile fatty acids:lactic acid, acetic acid and butyric acid. The content was measured by means of aWaters 2690 chromatograph with a Waters 2487 absorbance detector. The $\mathrm{pH}$ value of silages was determined by measuring the concentration of hydrogen ions with an electrode coupled with a WTW ph 730 InoLab pH-meter.

The results were statistically analyzed. The two-way analysis variance (ANOVA) were performed.

\subsection{Assessment of silage quality}

The measurements of the content ofvolatile fatty acids: lactic acid, acetic acid and butyric acid were used to assess the quality of silages according to the FliegZimmer scale. This method of assessment of silage quality is based on the percentage of volatile fatty acids in the total weight of silage.

\section{Results}

\subsection{Dry matter content}

The highest average content of dry matter was measured in the maize straw ensilaged in the heap, i.e. $76.63 \%$. The lowest content of dry matter was noted in the maize straw ensilaged naturally in film-wrapped bales, i.e. $40.23 \%$. The maize straw ensilaged in a flexible silo contained $48.72 \%$ of dry matter (Table 1 ).

The content of dry matter in the input material was $68.00 \%$. When the maize grain was harvested at the phase of full maturity, maize straw was ensilaged in a flexible silo with the CSS2 preparation. The method resulted in the smallest loss of dry matter, i.e. 5.71\%. There was a significantly greater loss of dry matter in the naturally ensilaged straw, i.e. $26.01 \%$. The ensilage in a flexible silo with the CSS1 preparation reduced the content of dry matter by $23.12 \%$.

Table 1. The content of dry matter in the silages, according to the ensilaging preparation and type of silo.

\begin{tabular}{|c|c|c|c|c|c|}
\hline Factors & & e of contai & (B) & & \multirow{3}{*}{$\operatorname{LSD}_{(0.05)}$} \\
\hline \multirow[t]{2}{*}{ Ensilaging preparation (A) } & $\begin{array}{c}\text { Ensilage } \\
\text { heap }\end{array}$ & $\begin{array}{c}\text { Film- } \\
\text { wrapped } \\
\text { bales }\end{array}$ & $\begin{array}{c}\text { Flexible } \\
\text { silo }\end{array}$ & Average & \\
\hline & \multicolumn{4}{|c|}{ Dry matter $[\%]$} & \\
\hline CSS1 & 73.58 & 45.07 & 41.88 & 53.51 & \multirow{4}{*}{$\begin{array}{c}\text { A } 0.734 \\
\text { B } 0.734 \\
\text { A*B } 1.272\end{array}$} \\
\hline CSS2 & 77.42 & 39.51 & 62.29 & 59.74 & \\
\hline CSSN & 78.88 & 36.13 & 41.99 & 52.33 & \\
\hline Average & 76.63 & 40.23 & 48.72 & & \\
\hline
\end{tabular}

The lowest content of dry matter was measured in the maize straw ensilaged naturally in film-wrapped bales, i.e. $36.13 \%$. The content of dry matter in the bales with the CSS2 preparation was $39.51 \%$, whereas the content of dry matter in the silage made with the CSS1 preparation was $45.07 \%$.

The content of dry matter in the naturally ensilaged straw was $73.58 \%$, with the CSS2 preparation $-77.42 \%$, with the CSS1 preparation - 78.88\%. There were statistically significant differences in the content of dry matter between these silages. The results of the analysis of the content of dry matter show that the process of maize straw ensilage was not initiated in the heap. If there is high content of dry matter in the substrate, it is difficult to condense it. As a result, there are adverse aerobic conditions and the silage becomes overheated, which results in the appearance of moulds and fungi.

\subsection{Volatile fatty acids}

The ensilage of feeds requires favourable conditions for the development of lactic acid bacteria. A stable silage should contain a large amount of lactic acid (1.5-3.5\%) and a medium amount of acetic acid (0.5-1.0\%). It might contain trace amounts of butyric acid (0.0-0.1\%).

There was diversified content of lactic acid in the silages - from $0.08 \%$ to $1.11 \%$. When we analyse the data referring to individual types of containers, we can see that the highest average content of lactic acid, i.e. $1.02 \%$ was found in the silages made in the flexible silo. The smallest average content, i.e. $0.18 \%$ was found in the silages made in the cylindrical bales. The average content of lactic acid in individual ensilage methods was less diversified and ranged from $0.60 \%$ in naturally made silages to $0.65 \%$ and $0.66 \%$ in silages with preparations CSS2 and CSS1 (Table 2). The difference in the average content of lactic acid between the silages with preparations and in the silage made naturally was statistically significant.

As results from the data, the content of lactic acid in the silages was below the required minimum due to the quality of straw.The high content of dry matter in the ensilaged maize straw may have caused problems in the development of lactic acid bacteria. In consequence, there was low content of lactic acid in the silages. 
Table 2. The content of lactic acid in silages according to the ensilaging preparation and type of silo.

\begin{tabular}{|c|c|c|c|c|c|}
\hline Factors & \multicolumn{3}{|c|}{ Type of container $(B)$} & \multirow[b]{2}{*}{ Average } & \multirow{3}{*}{$\operatorname{LSD}_{(0.05)}$} \\
\hline \multirow[t]{2}{*}{ Ensilaging preparation (A) } & $\begin{array}{c}\text { Ensilage } \\
\text { heap }\end{array}$ & $\begin{array}{c}\text { Film- } \\
\text { wrapped } \\
\text { bales }\end{array}$ & Flexible silo & & \\
\hline & \multicolumn{4}{|c|}{ Lactic acid [\%] } & \\
\hline CSS1 & 1.05 & 0.08 & 0.87 & 0.66 & \multirow{4}{*}{$\begin{array}{c}\text { A } 0.028 \\
\text { B } 0.028 \\
\text { A*B } 0.050\end{array}$} \\
\hline CSS2 & 0.59 & 0.29 & 1.07 & 0.65 & \\
\hline CSSN & 0.51 & 0.17 & 1.11 & 0.60 & \\
\hline Average & 0.72 & 0.18 & 1.02 & & \\
\hline
\end{tabular}

Table 3. The content of acetic acid in silages according to the ensilaging preparation and type of silo.

\begin{tabular}{|c|c|c|c|c|c|}
\hline Factors & \multicolumn{3}{|c|}{ Type of container (B) } & \multirow[b]{2}{*}{ Average } & \multirow{3}{*}{ LSD (0.05) } \\
\hline \multirow[t]{2}{*}{ Ensilaging preparation (A) } & $\begin{array}{c}\text { Ensilage } \\
\text { heap }\end{array}$ & $\begin{array}{c}\text { Film- } \\
\text { wrapped } \\
\text { bales } \\
\end{array}$ & $\begin{array}{c}\text { Flexible } \\
\text { silo }\end{array}$ & & \\
\hline & \multicolumn{4}{|c|}{ Acetic acid [\%] } & \\
\hline CSS1 & 2.60 & 0.31 & 0.23 & 1.05 & \multirow{4}{*}{$\begin{array}{c}\text { A } 0.121 \\
\text { B } 0.121 \\
\text { A*B } 0.209\end{array}$} \\
\hline CSS2 & 2.47 & 0.51 & 0.68 & 1.22 & \\
\hline CSSN & 0.69 & 0.20 & 0.67 & 0.52 & \\
\hline Average & 1.92 & 0.34 & 0.53 & & \\
\hline
\end{tabular}

Table 4. The content of butyric acid in silages according to the ensilaging preparation and type of silo.

\begin{tabular}{|c|c|c|c|c|c|}
\hline Factors & \multicolumn{3}{|c|}{ Type of container $(B)$} & \multirow[b]{2}{*}{ Average } & \multirow{3}{*}{$\operatorname{LSD}_{(0.05)}$} \\
\hline \multirow[t]{2}{*}{ Ensilaging preparation (A) } & $\begin{array}{c}\text { Ensilage } \\
\text { heap }\end{array}$ & $\begin{array}{c}\text { Film- } \\
\text { wrapped } \\
\text { bales } \\
\end{array}$ & Flexible silo & & \\
\hline & \multicolumn{4}{|c|}{ Butyric acid [\%] } & \\
\hline CSS1 & 0.14 & 0.13 & 0.03 & 0.10 & \multirow{4}{*}{$\begin{array}{l}\text { A } 0.044 \\
\text { B } 0.044 \\
\text { A*B } 0.076\end{array}$} \\
\hline CSS2 & 0.38 & 0.42 & 0.03 & 0.27 & \\
\hline CSSN & 0.06 & 0.24 & 0.02 & 0.11 & \\
\hline Average & 0.19 & 0.26 & 0.02 & & \\
\hline
\end{tabular}

The results of laboratory analyses showed that the highest average content of acetic acid, i.e. $1.22 \%$ was found in the silages with the CSS2 preparation. The smallest content, i.e. $0.52 \%$ was found in the silages prepared naturally. The average content of acetic acid in maize straw silages with the CSS1 preparation was $1.05 \%$ (Table 3 ).

There was a statistically significant increase in the content of acetic acid in the silages with the ensilaging preparations. This increase may have been caused by the fact that the inoculants containing lactic acid bacteria also contained substances stimulating the production of acetic acid. Acetic acid has positive influence on the aerobicstability of silages, which is important when a silage is collected from a silo.

The silages produced in the experiment also contained butyric acid. The smallest average content of butyric acid, i.e. $0.02 \%$ was found in the silage stored in the flexible silo. The highest average content, i.e. $0.26 \%$ was found in the silage made from film-wrapped bales. The analysis of variance showed that both factors under study resulted in the production of butyric acid in the maize straw silages (Table 4).

As results from the data, butyric acid was produced in all the silages. This means that there were some irregularities in the ensilaging process.

\subsection{The Flieg-Zimmer method}

The measurements of the content of volatile fatty acids:lactic acid, acetic acid and butyric acid were used to assess the quality of silages according to the FliegZimmer scale. The silages produced naturally and stored in the flexible silo and the silage inoculated with the CCS1 preparation were characterised by good quality, whereas the quality of the silage with the CCS2 preparation was satisfactory. 
Table 5. The ranking of maize straw silages according to the Flieg-Zimmer scale.

\begin{tabular}{|c|c|c|c|c|c|c|}
\hline \multirow{2}{*}{$\begin{array}{c}\text { Maize straw } \\
\text { ensilaged }\end{array}$} & \multirow[b]{2}{*}{$\mathbf{p H}$} & \multicolumn{3}{|c|}{ Volatile fatty acids [\%] } & \multirow[b]{2}{*}{ Score } & \multirow{2}{*}{$\begin{array}{c}\text { Quality } \\
\text { according to } \\
\text { Flieg-Zimmer } \\
\text { scale }\end{array}$} \\
\hline & & $\begin{array}{l}\text { Lactic } \\
\text { acid }\end{array}$ & $\begin{array}{c}\text { Acetic } \\
\text { acid }\end{array}$ & $\begin{array}{c}\text { Butyric } \\
\text { acid }\end{array}$ & & \\
\hline $\begin{array}{l}\text { Naturally in ensilage } \\
\text { heap }\end{array}$ & 7.76 & 0.51 & 0.69 & 0.06 & 23 & poor \\
\hline $\begin{array}{l}\text { With CSS1 } \\
\text { preparation in } \\
\text { ensilage heap }\end{array}$ & 7.35 & 1.05 & 2.6 & 0.14 & 22 & poor \\
\hline $\begin{array}{l}\text { With CSS2 } \\
\text { preparation in } \\
\text { ensilage heap }\end{array}$ & 7.43 & 0.59 & 2.47 & 0.38 & 8 & low \\
\hline $\begin{array}{l}\text { Naturally in film- } \\
\text { wrapped bale }\end{array}$ & 6.06 & 0.17 & 0.20 & 0.24 & 7 & low \\
\hline $\begin{array}{l}\text { With CSS1 } \\
\text { preparation in film- } \\
\text { wrapped bale }\end{array}$ & 7.96 & 0.08 & 0.31 & 0.13 & 0 & low \\
\hline $\begin{array}{l}\text { With CSS2 } \\
\text { preparation infilm- } \\
\text { wrapped bale }\end{array}$ & 4.91 & 0.29 & 0.51 & 0.42 & -4 & low \\
\hline $\begin{array}{l}\text { Naturallyin flexible } \\
\text { silo }\end{array}$ & 4.07 & 1.12 & 0.67 & 0.02 & 72 & good \\
\hline $\begin{array}{l}\text { With CSS1 } \\
\text { preparation in } \\
\text { flexible silo }\end{array}$ & 4.39 & 0.87 & 0.23 & 0.03 & 76 & good \\
\hline $\begin{array}{l}\text { With CSS2 } \\
\text { preparation in } \\
\text { flexible silo }\end{array}$ & 4.52 & 1.07 & 0.68 & 0.03 & 52 & satisfactory \\
\hline
\end{tabular}

The silages made in cylindrical bales had low content of lactic acid $(0.08-0.29 \%)$ and they contained butyric acid - their quality was low. The quality of the silages made in the prism was also low (Table 5).

The ensilaging capacity of vegetatively older green forages was reduced due to the increased content of raw fibre and reduced content of sugar. It was also a problem to displace air from the ensilaged mass. In consequence, sugars were additionally consumed in the process of respiration.

\section{Conclusions}

The research findings led to the following conclusions:

1. Maize straw with high content of dry matter can be used as a substrate for good quality silage.

2. A flexible silo is the best container for maize straw ensilage.

3. The results of the analysis of the content of dry matter show that the process of maize straw ensilage was not initiated in the ensilage heap.

4. The choice of the adequate ensilage method has significant influence on the quality of maize straw silage.

\section{References}

1. J. Dach, W. Czekała, P. Boniecki, A. Lewicki, T. Piechota. AMR 909, 305-10
(2014)doi.10.4028/www.scientific.net/AMR.909.30 5

2. E.M. White, G. Latta, R.J. Alig, K.E. Skog, D.M. Adams. Energy Policy 58, 64-7(2013) http://dx.doi.org/10.1016/j.enpol.2013.02.029

3. M. Monch-Tegeder, A. Lammer, H. Oechsner. Energy 73, 523-530 (2014). http://dx.doi.org/10.1016/j.energy.2014.06.051

4. S. Sokhansanj, S. Mani, S. Tagore, A. F. Biomass Bioenerg 34, 75-81 (2010). http://dx.doi.org/10.1016/j.biombioe.2009.10.001

5. CSO. Agriculture in 2015. (Warsaw 2016).

6. M. Cieślik, J., Dach, A. Lewicki, A. Smurzyńska, D. Janczak, J. Pawlicka-Kaczorowska, P. Boniecki, P. Cyplik, W. Czekała, K. Jóźwiakowski. Energy 115, 495-1502

(2016)http://dx.doi.org/10.1016/j.energy.2016.06.07 0

7. J. Przybył, W. Kot, D. Wojcieszak, N. Mioduszewska, D. Karol. Agricultural Engineering 4(148), 103-111 (2013)

8. M. Cieślik, J. Dach, P. Boniecki, D. Janczak, W. Czekała, A. Lewicki, P.C.R. Carmona, J. Pawlicka. ICEE Internatonal Conference on Energy \&Environmental 300-306 (2015)

9. K. J. Shinners, B. N. Binversie. Biomass Bioenerg 31, 576-584 (2007) 